担癌マウスの免疫能に関する研究

一免疫学的パラメーターとしてのリンパ球非特異的幼若化能に対する再検討——

滝田正亮・大野一夫・中沢光博

菅原利夫・作田正義

Immunological studies of tumor-bearing mice

_- Re-examination of nonspecific mitogen reaction of lymphoid cells as immunological parameter

Masaaki Takita - Kazuo Ohno : Mituhiro Nakazawa

Toshio Sugahara - Masayoshi Sakuda

I. 緒

言

各種 mitogen に対する非特異的リンパ球幼若化試験 は, 日常臨床においてその簡便さのために, 癌患者の

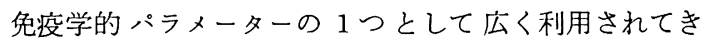
た アナロジーとも考えられ2). 種々の植物性レクチンは, 特異抗原を mitogen とするよりも高率に幼若化能を誘 発する2)ので, 比較的容易に行えるリンパ球機能検索法 である。一方, 症例数が重衫られるに従ってこの非特異 的幼若化能と, 抗腫瘍活性の主役と考えられる特異的細 胞障害活性とは，相関しないという報告が增えつつあ $ろ^{3 \sim 6)}$ また癌の病期との相関性以上に，担癌状態にお ける低蛋白血症や貧血など4), 他の因子による動摇が大 きく, 非特異的リンパ球幼若化能の免疫学的パラメータ 一としての困難性を指摘する報告例が少なくない, 4,5$)$.

そこで今回われわれは, 同一腫初に由来しながら抗原 性の異なる $2 つ の$ 腫瘍細胞を, 同系マウスに移植して, それぞれのマウスに出現する特異的リンハ球細胞障害活 性に, 非特異的リンパ球幼若化能がどれほど相関性を有 するかを検索し, 担癌生体に拈ける免疫学的パラメータ 一としての, 非特異的リンパ 球幼若化能の意義につい て，その再榆討を試みた。

大阪大学隧学部口腔外科学第 2 集座 （主任：作田正義教授）

The Second Department of Oral and Maxillofacial Surgery, Osaka University Dental School (Chief: Prof. Masayoshi Sakuda)

受付日：诏和58年 3 月 11 日

\section{II. 実験材料ならびに方法}

\section{1. 動 物}

動物は，大阪大学純系動物事業場より供給された生後 5 週粈の $\mathrm{ddO}$ 系雄マウスを使用した。

\section{2. 腫瘍材料および腫瘍の移植方法}

ポリオーマウィルス7) 由来の可移植性腫瘍8,9) (PVT

表 1 PVT 扰よび PVM の比校9

\begin{tabular}{|c|c|c|}
\hline \multicolumn{3}{|c|}{ PVT おょび PVM の性質 } \\
\hline & PVT & PVM \\
\hline ポリオーマウィルス産生 & $(-)$ & $(-)$ \\
\hline 組織学的所見 & 円形細胞肉腫 & 円形細胞肉腫 \\
\hline $\begin{array}{l}\text { 宿 主 } \\
\text { 担癌宿主の生存期間 }\end{array}$ & $\begin{array}{c}\mathrm{ddO} \text { 系マウス } \\
\quad 4 \sim 5 \text { 週 }\end{array}$ & $\begin{array}{c}\mathrm{ddO} \text { 系マウス } \\
\quad 6 \sim 7 \text { 週 }\end{array}$ \\
\hline 腫瘍形成に必要な細胞数 & $10^{5}$ & $10^{5}$ \\
\hline 移植または培養継代数 & 400 & 500 \\
\hline 世代時間 & $\begin{array}{c}22.5 \text { 時間 } \\
\left(\begin{array}{c}\text { PVT-C } \\
\text { ついて測定 }\end{array}\right)\end{array}$ & 19.0時閌 \\
\hline
\end{tabular}

\begin{tabular}{|c|c|c|}
\hline \multicolumn{3}{|c|}{ PVT 扣よび PVM の移植抗原性 } \\
\hline 宿 主 & 腫 瘍 & 腫瘍形成率 \\
\hline $\mathrm{ddO}$ & $\begin{array}{l}\operatorname{PVT}\left(1 \mathrm{~mm}^{3}\right) \\
\operatorname{PVM} \\
\left(5 \times 10^{5} / 0.1 \mathrm{ml}\right)\end{array}$ & $\begin{array}{l}11 / 11(100 \%) \\
11 / 11(100 \%)\end{array}$ \\
\hline $\mathrm{C}_{57} \mathrm{BL} / 6$ & $\begin{array}{l}\operatorname{PVT}\left(1 \mathrm{~mm}^{3}\right) \\
\operatorname{PVM} \\
\left(5 \times 10^{5} / 0.1 \mathrm{ml}\right)\end{array}$ & $\begin{array}{l}0 / 11(0 \%) \\
8 / 11(73 \%)\end{array}$ \\
\hline $\begin{array}{l}\mathrm{C}_{57} \mathrm{BL} / 6 \\
(\mathrm{PVT} \text { 拒紿マゥス })\end{array}$ & $\begin{array}{l}\mathrm{PVM} \\
\left(5 \times 10^{5} / 0.1 \mathrm{ml}\right)\end{array}$ & $0 / 11(0 \%)$ \\
\hline
\end{tabular}


と略す)，およびその in vitro の株化細胞9) (PVM と略 す）を移植腫䇠材料とし，一部の実験で PVTを primary culture した継代数 10 代以内の細胞 ${ }^{9)}$ (PVT-C) を使用した，PVM，PVT-C は10\% 仔牛血清（CS：阪

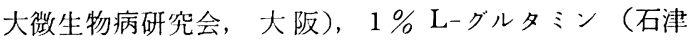
製薬，大阪）および重曹を含むイーグル最少必須培地 (MEM：日水製浆，東京）を用いて，37 ${ }^{\circ} \mathrm{C}, 5 \% \mathrm{CO}_{2}$ air の培荃器 (NAPCO 社製, USA) 中で培養し, 培差 液は 2 〜日ごとに交換した。なお， subculture および 実験供試時には， $0.05 \%$ トリプシン（阪大微生物病研究 会, 大阪)，および0.15\% EDTA (石津製薬, 大阪) を 含む $\mathrm{Ca}^{2+}, \mathrm{Mg}^{2+}$ 脱リン酸緩衝液 $(\mathrm{PBS}(-): \mathrm{pH}$ 7.2) （以下 EDTA-トリブシン溶液と略す）で細胞をシャー レ底面よりはがし，単個細胞浮遊液を作製した。

移植方法: PVT は約 $1 \mathrm{~mm}^{3}$ 大のブロック片として トロッカールを用い，また PVM は PBS (一) で調整し た $5 \times 10^{6}$ 個 $/ \mathrm{ml}$ の細胞浮遊液の $0.1 \mathrm{ml}$ を注射器を用 いて，それぞれマウスの背部皮下に移植した。

これら腫瘍細胞の諸性質については，米崎が詳細に報 告している9)

\section{3. エフェクター細胞の調整}

1）脾葴リンパ球の分離

マウスより無菌的に脾臓を摘出し，ステンレス網サイ トシーブ（\# 80）上でプラスチック棒を用いて磨り潰し た。その磨り潰した組織を RPMI 1640 培養夜（日水 製薬, 東京) 上に浮遊させ，軽くピペッティングを絽り 返して均等な細胞浮遊液とした。この細胞浮遊液から Conray (第一製薬, 東京) -Ficoll (Pharmacia, Uppsala, Sweden)（比重 1.09）を用いる比重遠沈法 ${ }^{10)}$ によ り、リンパ球に富む分画を採取した。

2) 末梢血リンパ球の分離

マウスより無菌的にへパリン添加注射器にて心臓穿刺 により採血を行った，RPMI 1640 培荃液にて 3 倍希釈 した後，1）と同様に Conray-Ficoll 比重遠沈法により リンハ球に富む分画を採取した。

\section{4. 脾臓 $\mathbf{T}$ リンパ球の分離}

上述 3-1）と同様に無菌的に脾荿を摘出し，磨り溃 して均等な 細胞浮遊液を作製する。この細胞浮遊液か ら, Nylon wool column 法11) によるT細胞に富む分画 を採取した。すなわち， $20 \mathrm{ml}$ の注射筒に脾細胞 $10^{8}$ 個 あたり $0.3 \mathrm{~g} / 3 \mathrm{ml}$ 目盛の割合で, Nylon wool（和光純 楽, 大阪) を充填して作製した Nylon wool column 中 で, 10\%牛胎旧血清 (FCS: Flow laboratories, USA) を含む RPMI 1640 培福液に浮逊させた脾細胞を $37^{\circ} \mathrm{C}$, 1 時間 incubate した後, 非付着性の column 通過細胞 を丁細胞に富む分画として採取した。

\section{5. 細胞障害試験}

Beanら ${ }^{12,13)}$ の $^{3} \mathrm{H}$ ーブロリン法に準趣して行った。図 1 にその概略を示す，70〜80\% confluent に增殖した標的
(標的細胞)

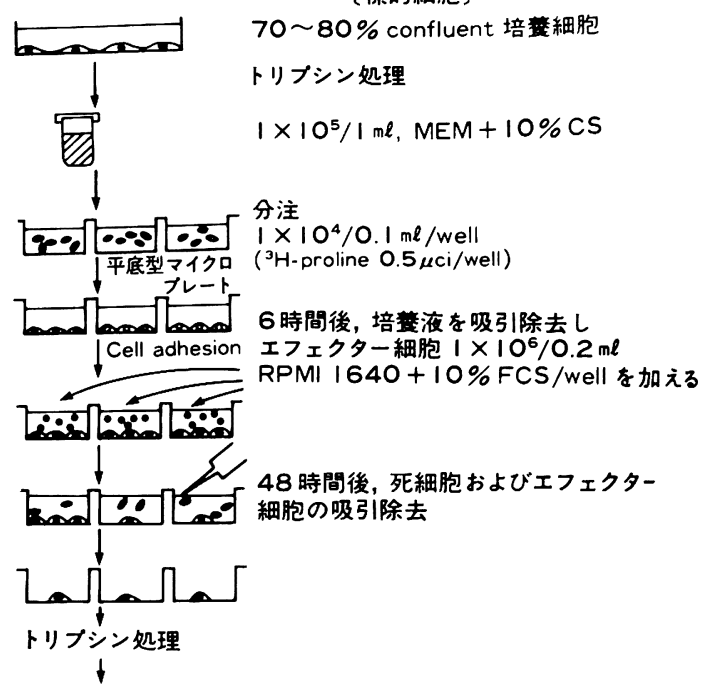

Cell harvesterにより残存生細胞を

glass fiber filter 上に採取 $\downarrow$

放射活性 $(\mathrm{cpm})$ の測定

図 1 細胞障害試験に用いた ${ }^{3} \mathrm{H}$-プロリン法の概略

表 $2{ }^{3} \mathrm{H}-$ プロリン法による標的細胞の標識感度

\begin{tabular}{|c|c|c|c|}
\hline $\begin{array}{l}\text { (1) } \\
\text { 標識時間 } \\
\text { (hr.) }\end{array}$ & 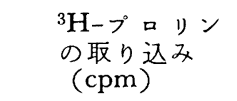 & $\begin{array}{l}\text { 培養時間 } \\
(\mathrm{hr} .)\end{array}$ & $\begin{array}{l}\text { 標識状態 } \\
(\mathrm{cpm})\end{array}$ \\
\hline 3 & $4805.3 \pm 495.0$ & 24 & $5607.0 \pm 397.0$ \\
\hline 4 & $5728.0 \pm 199.2$ & 48 & $5371.0 \pm 548.3$ \\
\hline 6 & $7850.0 \pm 988.6$ & 60 & $4163.0 \pm 653.4$ \\
\hline 8 & $9733.3 \pm 843.6$ & & \\
\hline$(2)$ & 処 理 & \multicolumn{2}{|c|}{ 標識状態 (cpm) } \\
\hline 1) & $\begin{array}{l}1 \times 10^{4} \text { 個，標識標 } \\
\text { 的細胞 (対照) }\end{array}$ & \multicolumn{2}{|c|}{$41980.2 \pm 2670.2$} \\
\hline 2) & $\begin{array}{l}1 \times 10^{4} \text { 個, 凍結・ } \\
\text { 融解 ( } 3 \text { 回) }\end{array}$ & \multicolumn{2}{|c|}{$3399.3 \pm 140.0$} \\
\hline 3 ) & 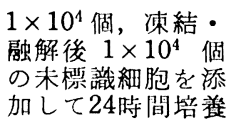 & \multicolumn{2}{|c|}{$2071.0 \pm 118.3$} \\
\hline
\end{tabular}

（1）縱線左は PVM 細胞 $1 \times 10^{4}$ 個/ 10\% CS 添加

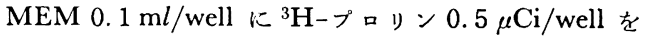

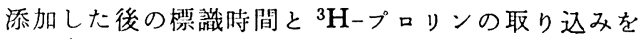
示す。縱線右は標識時問 4 時間の後, 培滛液を $10 \%$ FCS 添加 RPMI 1640 に交换して坮㸼を継続し, 各 㭙間後の標識状態を示す。

(2) 60〜70\% confluent に增殖した PVM を $10 \%$ $\mathrm{CS}$ 添加 $\mathrm{MEM} 3 \mathrm{ml}$ 中で, $10 \mu \mathrm{Ci} / \mathrm{ml}$ の ${ }^{3} \mathrm{H}-$ ブロ リンを添加して標識を行った後, 標識細胞の破烄に

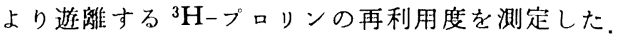
数值は各群 4 通り培溇して求めた平均值土標浛偏差 を走す。 
細胞（PVM あるいは PVT-C) を, EDTA-トリプシ ン溶液で処理して $10 \% \mathrm{CS}$ 添加 MEM 培養液による $1 \times 10^{5}$ 個 $/ \mathrm{ml}$ の細胞浮遊液を作製する。この細胞浮遊液 をプラスチックプレート（平底 96 well, Flow laboratories, USA) に $0.1 \mathrm{~m} l /$ well ずつ分注するが, 同時に ${ }^{3} \mathrm{H}$-プロリン (Specific activity; $41.07 \mathrm{Ci} / \mathrm{mmol} \mathrm{New}$ England Nuclear, USA) $0.5 \mu \mathrm{Ci} /$ well を添加し, 分注 した標的細胞がプレート底面に付着するまでの時間を利 用して，標的細胞の標識を行った．表 2 は培養時間と標 識状態との関係を示す。付着完了後培養液を吸引除去 し, 10\% FCS 添加 RPMI 1640 培養液にて $5 \times 10^{6}$ 個/ $\mathrm{ml}$ のリンパ球が含まれるように調整したェフェクター 細胞浮遊液を， $0.2 \mathrm{ml} /$ well ずつ分注した（エフェクタ 一細胞に対する 標的細胞の比, 寸なわち $\mathrm{E} / \mathrm{T}$ ratio= 100).なお，対照にはェフェクター細胞を含まずに, 10 \% FCS 添加 RPMI 1640 培盖液 $0.2 \mathrm{ml}$ のみを分注し ておいた。 $37^{\circ} \mathrm{C}, 5 \% \mathrm{CO}_{2}$-air の培養器中で 48 時間静 固培養し，培着終了時に浮遊した死細胞を吸引除去した 後, プレート底面に付着している残存生細胞を EDTAトリプシン溶液で剝雄し，Automatic cell harvester (LM-101 ラボマッシュ; ラボサイェンス, 東京) により glass fiber filter (ラボサイェンス, 東京) 上に採取し た.この filter を乾燥後, 標的細胞に標識されている ${ }^{3} \mathrm{H}-$ プロリンの放射活性 (cpm) を, 常法 ${ }^{14)} に$ 従って, 液体シンチレーションスペクトロメーター(Aloka LGL163 ; Aloka Co., 東京) を用いて测定した。培養は実験 群とェフェクター細胞を添加しない対照群とを，それぞ れ $3 \sim 5$ 通り行い, それらの平均値から以下の計算式に より\% cytotoxicity を求めた。なお各培養群での標準 偏差は，打おむね平均值の10\%以内であった。

$$
\% \text { cytotoxicity }=\frac{\text { 対照群 } \mathrm{cpm}-\text { 実験群 } \mathrm{cpm}}{\text { 対照群 } \mathrm{cpm}} \times 100
$$

\section{6. リンパ球幼若化試験}

リンパ球を，10\% FCS 添加 RPMI 1640 培養液で $1 \times 10^{6}$ 個 $/ \mathrm{m} l$ の細胞浮遊液に調整して，その $0.2 \mathrm{ml}$ ず つをプラスチックプレート（平底，96 well）の各 well に分注し， $37^{\circ} \mathrm{C}, 5 \% \mathrm{CO}_{2}$-air の培養器中で 48 時間培 養した。培坫終了24時間前に $1 \mu \mathrm{Ci} /$ well の ${ }^{3} \mathrm{H}$-チミジ ข(Specific activity; $8.3 \mathrm{mCi} / \mathrm{mg}$, The Radiochemical Center, England) を添加し，培荃終了時に上述 5 と同 様に Automatic cell harvester を用いてリンパ球を採取

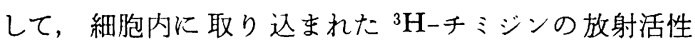
(cpm) を测定した。 mitogen は Con A (Sigma Chemical Co., USA), および PHA (Difco, USA) を使用 し, 幼若化能の検討には mitogen 無添加の対照培養に 対する mitogen 添加培荃の比，すなわち Stimulation index (S.I.) を用いた。なお，各群の培羕は実験群，対 照群ともそれぞれ 3 〜 通り行い，それらの平均値から S.I. を求めた。各培養群での標準偏差は平均值の $10 \%$ 以
内であった。

\section{7. 末梢血リンパ球数の測定}

3-2）と同様の方法で採血を行い, 白血球計算用チュ ルク試液を用いて，Bürker-Türk 型血球計算䑾上で白血 球数を算定した。ささらに同血液の塗抹摽本について, メ チルアルコール固定後, ギムザ染色によりリンパ球の百 分率を求め $1 \mathrm{~mm}^{3}$ 当たりのリンパ球数を算出した。

\section{III. 結果}

表1に示したよらに，PVT，PVM 雨担癌マウスで は，その生存期間が多少異なるが，両担癌マウスとも 4 〜 5 週を越えると, 移植腫瘍部の潰瘍形成に伴って，各 リンパ球機能の個体差間での動摇が大きくなるため, 各 機能の活性值が比較的安定して検出できる 4 週目まで を，本研究の実験対照とした。 また，各 stage について いえば，両担癌マウスともおおむね以下のような経過を たどるものである。すなわち，移植後 1 週目頃まで：担 癌初期, $1 \sim 2,3$ 週目頃：担癌中期， 4 週目以降：担癌 後期.

\section{1. 特異的細胞障害性の経時的変動}

腫瘍移植後各時期の担癌マウスより採取した脾臓，お よび末梢血リンパ球をェフェクター細胞として，それぞ

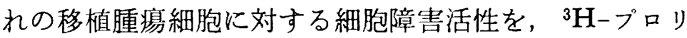
ン法により検索した。 なお，PVT 担癌マウスの系で は，PVT は固型腫瘍なので，PVT-C を標的細胞とし て使用した。ちなみに，PVT，PVM の両腫瘍細胞では その移植方法が異なっているが，肺への転移率や宿主、 ウスに発現する抗腫瘍活性は，移植方法の違いにより変 化しないことが確められている9)

PVT 担癌マウスでは, 図 2 に示すように, ェフェク ター細胞を末梢血リンハ球とした場合と，脾臓リンパ球 とした場合とでは，検出される活性測定值には大きな差 が認められるが，兩リンハ球 source とも，ほぼ同様な 経時的変動パターンが観察された。すなわち，両リンパ 球 source とも， 3 週目頃をピークとする 単峰性の経時 的パターンを示していた，一方，PVM 担癌マウスの系 では, 図了に示されるように各時期の両リンパ球 source 中には，ほほ同程度の 細胞障害活性が 検出できたが， PVT 担癌マウスの系の変動パターンとは明らかにその 様相を異にしていた。すなわち，(1) 非担癌（正常対 照）マウスから採取したリンハ球にも高い細胞障害活性 が検出されること，（2）1 週目と 3 週目をピークとする 2 峰性の変動ハターンを示すこと, 以上 $2 つ$ 点が注目 される。

\section{2. 非特異的リンパ球幼若化能の経時的变動}

腫瘍移植後各時期より採取した脾葴，および末梢血り ンパ球による T細胞 mitogen に対する非特異的リンパ球 幼若化能を検索した。図 4〜7に示すように, PVT 担 


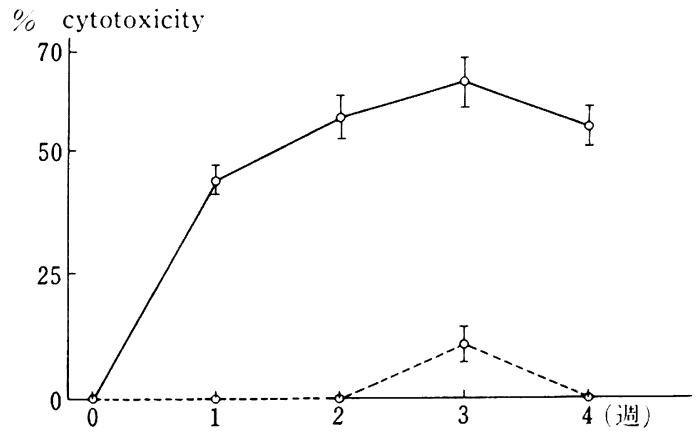

図 2 PVT 担痹マウスに打る細胞障害活性の経 時的変動

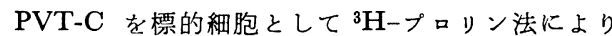
測定した。実線は脾缄りンパ球，点線は末梢血リン パ球をェフェクター細胞とした場合を示す。各測定 值はマウス $3 \sim 5$ 匹分の平均値土標準偏差を示す.

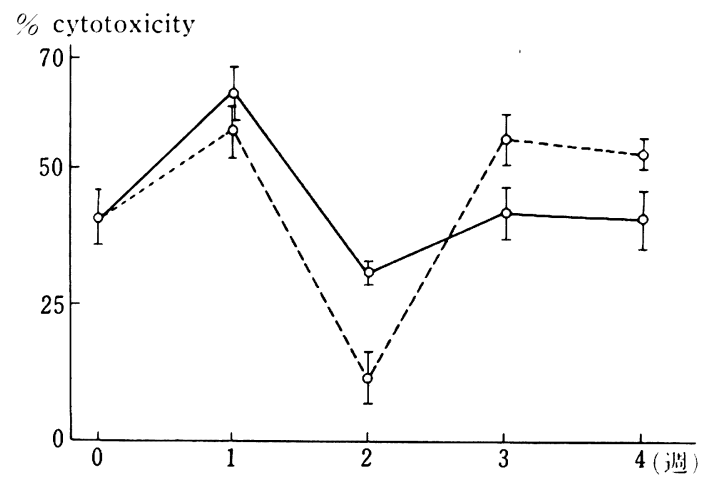

図 3 PVM 担瘦マゥスに扩ける細胞障害活性の経 時的变動

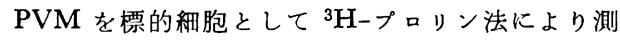
定した。図 2 と同様に，実線は脾珹リンハ球，点線 は末梢血リンパ球をェフェクター細狍とした場合 で, 各測定值はマウス $3 \sim 5$ 匹分の平均値土標準偏 差を示す。

癌マウスにおける 2 週目の末梢血リンパ球による高い幼 若化率や, mitogen の差による discrepancyなと，多少 の例外を除いては両担癌マウス, 両リンパ球 source と もに，おおむね一定傾向の変動パターンが覞察された。 すなわち, 腫瘍移植後 1 週目で著明に低下した後, 以後 は各時期ともに低応答性を示しており, 一応病期の進行 との相関性は示唆されたが, 上述の細胞障害活性の変動 パターンとの相関性は, 何ら認められなかった.

\section{3. リンパ球数の変動}

担癌各時期における脾缄，および末梢血りンパ球数の 経時的変動を検索した（図 8 および9）。なお，脾臓で の全リンパ球数の検索では一定傾向が得られにくいの

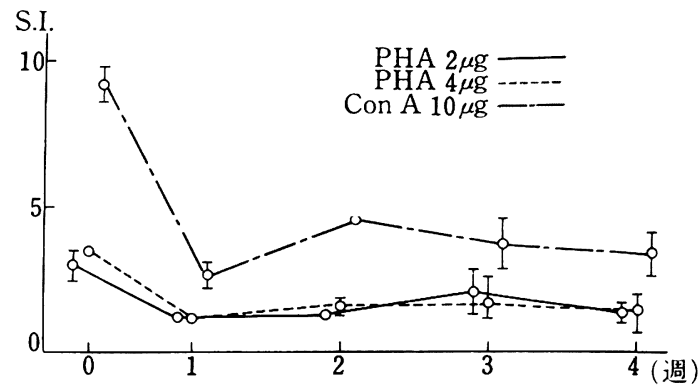

図 4 PVT 担癌マウスの脾藏リンパ球による幼若 化率の経時的変動

各群ともマウス $3 \sim 5$ 匹分の平均値土標準偏差を 示す。

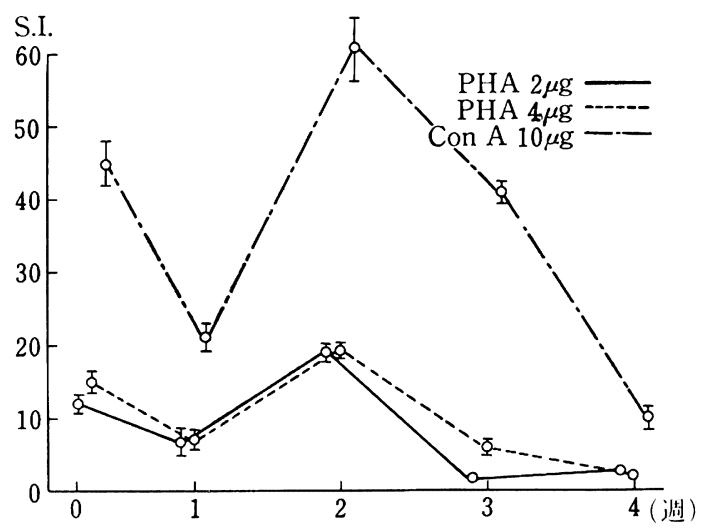

図 5 PVT 担瘦マウスの末梢血リンパ球による幼 若化率の経時的変動

各群ともマウス $3 \sim 5$ 匹分の平均値土標準偏差を 示す.

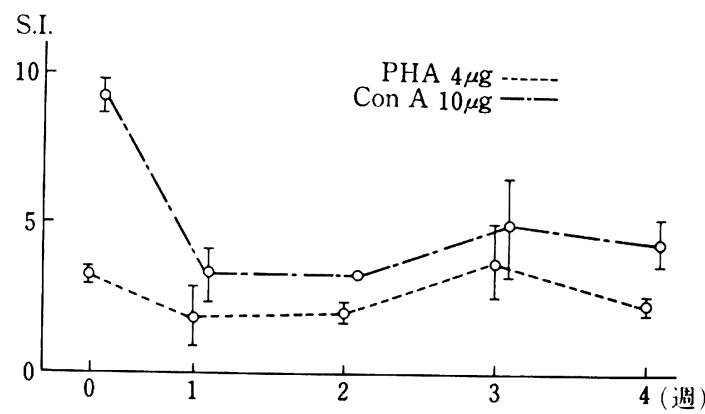

図 6 PVM 担癌マウスの脾臓リンパ球による幼若 化率の経時的変動

各群ともマウス $3 \sim 5$ 匹分の平均值土標淮偏差を 示す.

で，全有核細胞数に対する Nylon wool column 通過細 胞数の\%表示, すなわち， T細胞数の割合を検討した。

両担癌マウスとも，脾臓と末梢血リンパ球数はそろっ 


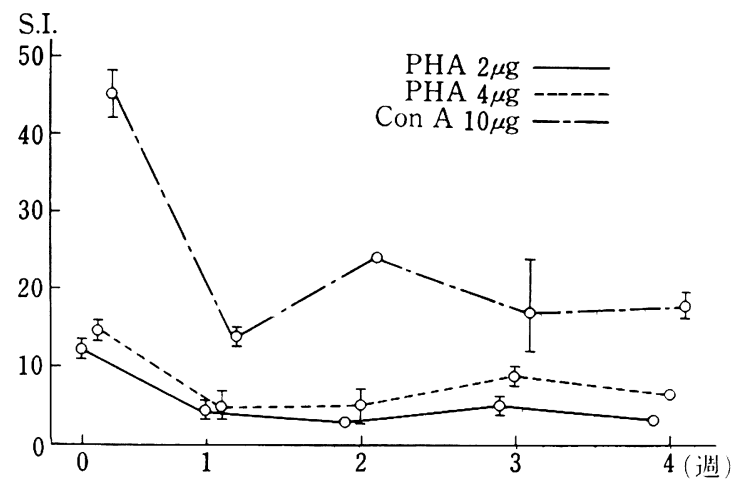

図 7 PVM 担痹マウスの末梢血リンパ球による幼 若化率の経時的変動

各群ともマウス 3 マ 5 匹分の平均値土標準偏差を 示す.

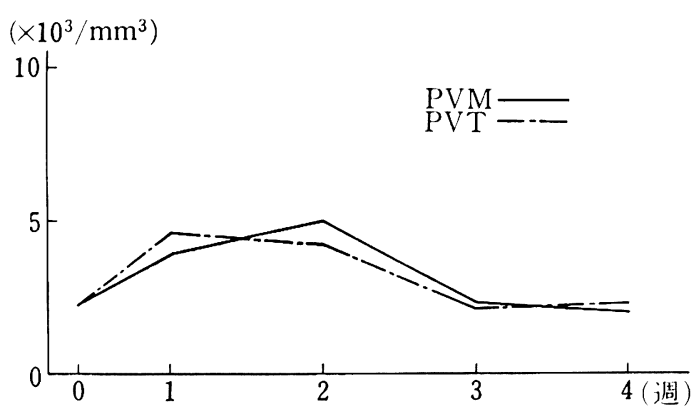

図 8 PVT, PVM 両担癌マウスに拈ける末梢血リ ンパ球数の経時的変動

各時期の数值はマウス $3 \sim 5$ 匹分の平均値を示 †.

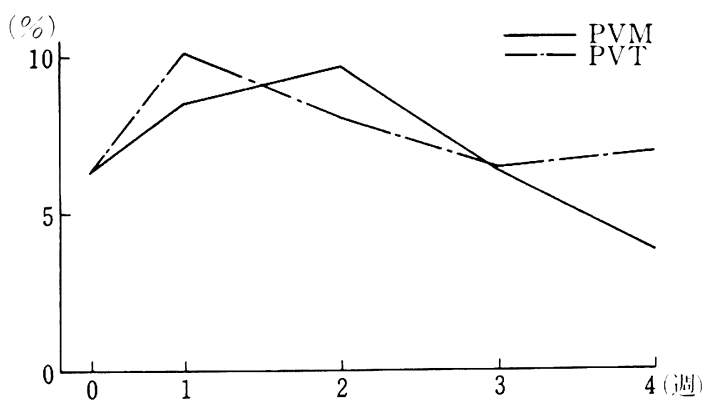

図 9 PVT, PVM 両担瘦マウスに扩る脾缄 Tリ ンパ球量の経時的変動

各時期の数值はマウス $3 \sim 5$ 匹分の平均值を示 す

て移植後一過性に增加した後, PVT 担癌マウスは 1 週 目より，PVM 担癌マウスでは 2 週目より，それぞれ低 下傾向を示していた。したがって，雨担癌マウスでみら
れた細胞障害活性の特徵的な変動パターンや, 担癌 1 週 目における非特異的リンパ球幼若化率の低下など, 機能 の変動を裏付けるような量的な変動は, リンパ球全体の 動きからは認められなかった。

\section{IV. 考察}

本研究は, 簡便で実用的な非特異的リンハ球幼若化試 験と, 免疫学的パラメーターとして, より合目的と考え られる特異的リンパ球細胞障害活性との相関性につい て, 同系の宿主一腫瘍系を担癌モデルとして再検討した むのである。

結果 1 で述べたPVM 担癌マウスの系で観察された抗 PVM 活性の5ち, 正常対照群, および腫㾤移植後 1 週 目で検出される高活性値は, NK 活性単独によるもので あり, PVM 担癌マウスに出現する実際の特異的リンパ 球細胞障害活性は，2週目以降であることが, 別の研究 結果から明らかにされている15) これに対して，PVT 担癌マウスの系で観察された細胞障害活性は, すべて特 異的リンパ球細胞障害活性である ${ }^{15)}$ 米崎の行った移植 抵抗性試験の結果 (表 1) は, 両腫瘍細胞の抗原性の違 いを示すものであり, PVT および PVM 再担癌マウス に扣ける細胞障害活性の変動ハターンの差は、これら移 植腫瘍の抗原性の差が, 宿主に拈ける抗腫瘍活性の誘導 に，影響を及ぼした結果と考えられる。

さて, 本研究で用いた 2 つ担癌モデルにおいても, 確かに担癌時期の進行とともに, 非特異的リンパ球幼若 化能の低応答性が認められ, 担癌生体における一般的免 疫能の低下を示唆する結果が得られた。しかし, 担癌初 期で，いまだ細胞障害活性の出現途上と考えられる 1 週 目において，すでに幼若化能の低下がみられるなど，解 釈に不可解な点が存在していた。これに対する最も考え られやすい原因としては，両リンパ球 source から移植 局所への mitogen 応答細胞の流出という, 量的な変動 に基つく可能性があげられる。 しかし，結果で述べたご とくリンパ球全体の分布変動, および移植局所のリンパ 球浸潤度の 経時的推移16) から検討すると, この可能性 は少ないようである。またこのような担癌初期にお ける一般的免疫能の 低下に関連性を有するものには, “dilution escape”として知られている現象がある17,18). これは微弱な抗原刺激では，か方ってサプレッサーT細 胞 (Ts) が活性化されるために, 宿主に免疫抑制作用が 発現するもので, 移植初期における一時的なリンパ球機 能低下の説明には，都合のよいものである。樫村ら ${ }^{19)}$ も, 担癌生体のリンパ球の mitogen に対する低応答性 は, その応答細胞の減少に原因するのではなく, 癌細胞 により能動化される Tsによるものであると報告してい る。しかしながら，本実験系で観察された mitogen に 対する低応答性については，同一時期に細胞障害活性が 
高率に検出されるといら理由から，いちがいに Ts にそ の原因を求めることは難しいよらである，実験に用いる 宿主一腫瘍系のタイプにより，また，同一宿主一腫瘍系 においても担癌時期により, リンハ球幼若化能の低下の 機棤は異なると考えられるので, この点については, 今 後さらに検索を進める必要があり，病期との相関性のな いリンハ球幼若化能の低下には, 特に慎重な検討が必要 と思われる。

緒言でも述べたように，非特異的リンバ球幼若化能と 特異的細胞障害活性とが，必ずしも相関しないといら現 象について，近年次第にその報告例が增えつつあり，前 者はその簡便さにもかかわらず, 免疫学的ハラメーター としての困難性が強調されつつある，その原因について は，種々の 文献記載 ${ }^{20-22)}$ を参考にしてまとめると，お おむね以下のように要約することができる。すなわち, 双方とも $\mathrm{T}$ 細胞が主体をなす in vitro に拈ける一現象で あるが，（1）非特異的 mitogen 応答細胞と, 細胞障害 活性を担らリンバ球とでは，そのポピュレーショが同一 ではない，(2) 各種レクチンに対するレセプターと，標 的細胞の抗原決定基に対する特異レセプターとは, その 発現様式が異なる，（3）培養条件，ことに細胞障害活性 の測定系では，種々の影響因子による検出感度の動摇が 大きいこと，などである。また，一般的にリンパ球幼若 化能は, 宿主の異栄養状態下でも低下することが知られ ている ${ }^{23,24)}$ が，細胞障害活性は必ずしもそうとは限ら ず25), 宿主一腫湟系によっては, 腫湯移植後経時的に上 昇する細胞障害活性が，宿主の腫瑒死直前で最高值を示 す例の報告 ${ }^{26)}$ もあり, 雨活性機能の宿主側因子に対する 感受性にも，差が存在するようである。

リンハ球幼若化能の测定では検出し得ない抗腫瘍因子 で，最近急速に関心が高められているものに NK 細胞 がある27 30) PVM 担癌マウスの系に出現する細胞障蹇 活性にこの NK 細胞が関連していることは前述した が, 移植腫場細胞の NK 細胞感受性については, PVT は NK 非感受性腫瘍, PVM は NK 感受性腫瘍である ことが判明している(5)。移植宿主における特異的細胞障 害活性として検出される测定値は，標的細胞の NK 感 受性により影響されること，あるいは移植腫瘍の NK 感受性が，インターフェロンを介する宿主 NK 活性の 上昇機構に関連する ${ }^{29)}$ など，腫場細胞の NK 感受性が 宿主の細胞障害活性の発現に，重要な因子となることが 報告されている.

そのよらな NK 細胞が，はたして in vitro のみなら ず in vivo に拈いても，抗腫㻛活性の担い手になりらる かどらかについては，現在のところ議論の対象である が31 33)，われわれの用いた宿主一腫瘍系では，NK 活 性を含めた細胞障害活性の経時的変動が，肺転移形成率 の経時的変化 $\left.{ }^{9}\right) に$ 実によく相関することが注目される。 NK 感受性腫婸 PVM を移植したマウスでは，特異的
細胞障害活性の出現は, PVT 担癌マウスに比較する と, 遅延し 2 週目以後であるが, NK 活性の高い 1 週目 頃までは肺転移率は低く，NK 活性の低下に伴い肺転移 率は增加していった。一方, NK 非感受性腫瘍 PVTを 移植したマウスでは，NK 活性しか検出し得ない移植早 期には高い肺転移率が認められたが，特異的細胞障害活 性の速やかな出現に伴って, 肺転移率は減少していっ た。

すなわち，移植腫瘍が同一腫瘍に由来しても，免疫原 性および免疫感受性の差によって，宿主の肺転移率の経 時的変化には，差が生じることが示唆される。このよう に, 宿主の予後を左右する重大な転移現象と, 細胞障害 活性との間にはきわめて強い相関性が認められたが，非 特異的リンハ球幼若化能との相関性は，見い出すことが できなかった。ちなみに，PVM 担癌マウスの 2 週目で 観察された細胞障害活性 (NK 活性) の低下は, 担癌宿 主の有する免疫抑制機構に原因するものではなく、エフ ュクター細胞の “convert”，すなわち，NK 細胞から細 胞障害性 Tリンパ球 (CTL) への “convert” に基づく 可能性が示咬されている15)。移植腫瘍の抗原性によって 修飾される宿主の細胞障害活性の変動には，免疫担当細 胞間における複雑な相互作用のほかに，このようなエフ ェクター細胞の “lineage” に基づく影響なども，複雑な 因子として関わり合っている可能性を考虙しなければな らないと思われる. 前述した「3つの要因」に加えて, これら非特異的リンパ球幼若化能では検出できない複雑 な因子を念頭に置くならば，免疫学的パラメーターとし て, より合目的な特異的リンハ球細胞障害活性と, 非特 異的リンハ球幼若化能との相関性を求めることは, 到底 困難なものになると考えられる。

一般に同系腫瘍で免疫した際には, ウィルス関連抗原 や強い腫場特異抗原をもつものを除いては, in vivoで の細胞障害性 $\mathrm{T}$ リンパ球の誘導は難しいとされてい る34).したがって, 本系で観察された両免疫学的パラメ 一ターの discrepancy は, 著者らが用いた系, すなわち 特異的リン八球細胞障害活性が強く誘導される系におい て, 特に增幅されてみられる可能性もあり, 得られた結 果をたたちに臨床面に結びつけるのは早計であるが，し かし今後日常臨床に拈いて, 免疫学的パラメーターとし て非特異的リンパ球幼若化試験を行ら場合, 念頭に置か なければならない問題点を, 再度提示するものである.

\section{V. 結語}

われわれは, 同一腫洨に由来するが抗原性の異なる 2 つの腫瘍細胞を，それぞれ同系マウスに䔟植して，それ ぞれの担癌マウスに発現する紐胞障辊活性，扣上び非特 異的リンパ球幼若化能の経時的変動を検索した。さらに 阿活性機能の関連性を追求することにより, 非特異的り 
ンパ球幼若化能の货疫学的パラメーターとしての意義に ついて，その再檢討を試みた。その結果，担癌後期にお。 けるリンパ球幼若化能の低下は，一応らなずける結果で あったが，担癌初期〜中期の宿主免疫応答状態が微妙に 変動する時期では，その免疫学的パラメーターとしての 困難性が, 強く示唆された。

\section{引用 文 献}

1) 山村雄一, 他編：がん稩胞と免疫細胞。初版, 講談社, 東京, 1978, 59面。

2) 畔柳武雄, 他編: 新免疫学酸書 5 , 免疫の生化 学. 初版, 医学書院, 東京, 1980, 171頁.

3) Kirchner, H., et al.: Evidence of suppressor cell activity in spleens of mice bearing primary tumors induced by Moloney sarcoma virus. J Exp Med 139: 14731974.

4) 岡林謙蔵, 他. 胃がん患者に扣ける免疫能の推 移の検索。第 39 回日本癌学会総会記事：108 1980.

5）柳川悦朗，他：胃がん患者リンハ球の幼若化能 之腫瘍細胞障害能。第39 回日本癌学会総会記 事: 1101980.

6) 山本 悟, 他 : 担瘦生体に捕ける特異的 - 非特 異的免疫能の関連一一臨床的・実験的研究—. 第41回日本癌学会総会記事：149 1982.

7) Stewart, S.E., et al.: Progress in virus research-The polyoma virus. Progr Exp Tumor Res 1: 671960.

8) 米崎英樹, 他: Polyoma virus 由来の可移植性 腫㻛の樹立について。科誌 21：496 1972.

9) 米崎英樹：担癌宿主の免疫能と転移形成に関す る基礎的研究. 阪大透学誌 23：232 1978.

10) Böyum, A.: Separation of leucocytes from blood and bone marrow. Scan J Clin and Lab Invest 21 (Supp. 97): 771968.

11) Julius, M.H., et al.: A rapid method for the isolation of functional thymus-derived murine lymphocytes. Eur J Immunol 3: 6451973.

12) Bean, M.A., et al.: Prelabeling target cells with ${ }^{3} \mathrm{H}$-proline as a method for studying lymphocyte cytotoxicity. Natl Cancer Inst Monogr 37: 411973.

13) Bakács, T., et al.: Characterization of human lymphocyte subpopulations for cytotoxicity against tumor-derived monolayer cultures. Int J Cancer 19: 4411977.

14）石河宽炤：液体シンチレーション测定法。初 版, 南山堂, 東京, 1977, 112頁。

15）滝田正亮：担癌マウスに扣ける抗腫疾活性につ いての研究—NK N 細胞と CTL との関連性に ついて——阪大菌学誌 28 巻揭戍予定.

16)滝田正亮, 他：担癌宿主生体に扣けるリンパ球 機能の経時的変動について, 口科誌 $31: 625$
（第36回日本口腔科学会総会抄録） 1982 .

17) Kölsch, E., et al.: Low zone tolerance and suppressor $\mathrm{T}$ cells. Transplant Rev 26:56 1975.

18) Bonmassar, E., et al.: Differential reactivity of mice to alloantigens associated with the D and $\mathrm{K}$ end of H-2. Transplant 12: 3141971.

19）樫村博正，他：癌患者に扣计る抑制性 $\mathrm{T}$ 細胞に 上る稩胞性免疫抑制機模。第40回日本癌学会総 会記事：1331981.

20) Tsukuda, M., et al.: Lymphoproliferative response to menbrane extracts of nasopharyngeal cartinoma. Gann 71: 4411980.

21) 畔楖武婎, 他編・新免疫学领装 2 ; 免疫応答. 初版, 医学曺院, 東京, 1979, 18面。

22) 網野信行：Killer 紐胞活性の検査。臨床病理 (臨時增刊第45号)：79 1981.

23) Holm, G.: Acute energy derivation in man: effect on cell-mediated immunological reactions. Clin Exp Immunol 25: 2071976.

24）近藤芳夫, 他: 癌治療と栄湌. 初版, 䜄談社, 東京, 1980,66 頁.

25）今野金裕，他：栄晅障富。臨床免疫 13：999 1981.

26) Zöller, M., et al.: Specific cytotoxicity in vitro by $\mathrm{T}$-cell-enriched lymphocyte subpopulations from rats bearing chemically induced but not spontaneous tumors. J Natl Cancer Inst 65: 7691980 .

27) Herberman, H.B., et al.: Natural killer cells: Characteristics and regulation of activity. Immunological Rev 44: 431979.

28) Kiessling, R., et al.. An analysis of the murine NK cell as to structure, function and biological relevance. Immunol Rev 44: 1651974.

29) Welsh, R.M., et al.: Mouse natural killer cells: Induction specificity, and function. J Immunol 121: 16311978.

30) Herberman, R.B., et al.: Natural cell-mediated immunity against tumors. edl, Academic press, New York, 1980, p 1.

31) Chow, D.A., et al.: Macrophage-dependent, NK-cell-independent "Natural" surveillance of tumours in syngeneic mice. Int $\mathrm{J}$ Cancer 23: 7881979.

32) Riccardi, C., et al.: In vivo natural reactivity of mice against tumor cells. Int $\mathrm{J}$ Cancer 25 : 4751980.

33) Gorelik, E., et al.. Radioisotope assay for evaluation of in vivo natural cell-mediated resistance of mice to local transplantation of tumor cells. Int J Cancer 27: 7091981.

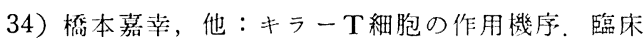
免疫 13:98 1981 . 